\title{
HUBUNGAN MOTIVASI,SEMANGAT KERJA DAN KEPUASAN KERJA DALAM PSIKOLOGI MANAJEMEN
}

\author{
Eci Sarmila ,17002121 \\ Email : ukhtfillaheci.unp@gmail.com
}

\begin{abstract}
ABSTRAK
Motivation is a condition that moves employees to achieve goals, while job satisfaction is a feeling that supports the employee and relates to his work or with his condition, motivation is related to job satisfaction, which is the higher the motivation of a person, the higher the level of one's job satisfaction feelings related to work involve aspects such as wages, salary received, health, ability, education and so on. The purpose of writing this article is to determine the effect of the relationship between motivation, work enthusiasm and job satisfaction
\end{abstract}

Kata kunci : Motivasi,kepuasan kerja,dan semangat kerja.

\section{A.PENDAHULUAN}

1. Latar belakang

Manusia lahir dengan kebutuhan-kebutuhan fisik.Mereka kemudian memperoleh ataupun mengembangkan sejumlah besar kebutuhan yaitu kebutuhan-kebutuhan social dan egoitis.Kebutuhan-kebutuhan psikologi yang bari timbul dapat dapat dianggap sebagai perkembangan dari 1. Kebutuhan fisik.2.Ssistem sraf dan tubuh dan

3. Ketergantungan kepada orang lain.Oramg-oramg dapat membuat letergantunga itu cenderung memuaskan atau cenderung menimbulkan frustasi sedangkan frustasi mengembangkan kebutuhan-kebutuhan akan rasa tak aman,permusuhan dan egois

2. Rumusan masalah 
Dari latar belakanhg diatas dapat ditarik rumusan masalahnya yaitu bagaimana hubungan motivasi,semangat kerja dan kepuasan kerja.

\section{Tujuan penulisan}

Tujuan penulisan artikel ini adalah untuk mengetahui bagaimana keterkaitan antara motivasi,semangat kerja dan kepuasan kerja pegawai.

\section{B. PEMBAHASAN}

\section{A. MOTIVASI}

\section{Pentingnya Motivasi}

Tanpa adanya motivasi dari para karyawan untuk bekerja,maka tujuan yang telah ditetapkan tidak akan tercapai.Sebaliknya,apabila motivasi yang tinggi dari karyawan,maka hal itu merupakan suatu jaminan atas keberhasilan suatu organisasi untuj mencapai tujuannya (gitosudarmo,2001).Oleh karena itu manejer harus menimbilkan motivas kerja yang tinggi pada karyawannya guna melaksanakan tugastugasnya,sekalipun motivasi bukan salah satu-satunya faktor yang mempengaruhi tingkat prestasi kerja seseorang.Timbulnya motivasi dikarenakan seseorang merasakan suatu kebutuhan tertentu dan karenanya perbuatan tersebut terarah pada pencapaian tujuan tertentu.

\section{Faktor Yang Mempengaruhi Motivasi}

Motivasi sebagai proses psikologis dalam diri seseorang akan dipengaruhi oleh beberapa faktor.Fakor-faktor tersebut dapat dibedakan atas fakor intern dan ekstern yang berasal dari karyawan.

\section{Faktor intern}

Faktor intern yang daoat mempengaruhi pemberian motivasi pada seseorang antara lain : 
a. Keinginan untuk dapat hidup

Keinginan untuk dapat hidup merupakan kebutuhan setiap manusia yang hidup dimuka bumi ini,keinginan untuk dapat hidup meliputi kebutuhan untuk :

Memperoleh kompensasi yang memadai.

> Pekerjaan yang tetap walaupun penghasilan tidak begitu memadai.

Kondisi kerja yang aman dan nyaman.

b. Keinginan untuk dapat memiliki

Keinginan untuk dapat memiliki benda dapat mendorong seseorang untuk melakukan pekerjaan.

c. Keinginan untuk memperoleh penghargaan

Seseorang mau bekerja disebabkan adanya keinginan untuk diakui,dihormati .

d. Keinginan untuk memperoleh pengakuan

Bila kita perinci,maka keinginan untuk memperoleh pengakuan itu dapat meliputi hal-hal berikut :

$>$ Adanya penghargaan terhadap prestasi.

> Adanya hubungan kerja yang harmonis dan kompak,

$>$ Pimpinan yang adil dan bijaksana,dan lai sebagainya.

\section{Faktor ektern}

Faktor ekstern juga tidak kalah peranannya dalam melemahkan otivasi kerja seseorang.Faktor ekstern itu adalah :

a. Kondisi lingkungan kerja

Lingkungan pekerjaan adalah keseluruhan sarana dan prasarana kerja yang ada disekitar karyawan yang sedang melakukan pekerjaan.

b. Kompensasi yang memadai 
Kompensasi merupakan sumber pengahasilan utama bagi para karyawan untuk menghodupi diri beserta keluarganya.

c. Supervisi yang baik

Fungsi supervisi dalam suatu pekerjaan adalah memberikan pengarahan,membimbing kerja para karyawan,agar adapat melaksanakan kerja dengan baik tanpa membuat kesalahan.

d. Adanya jaminan pekerjaan

Setiap orang akan mau bekerja mati-matian mengorbankan apa yang ada pada dirinya untuk perusahaan,kalau yang bersangkutan merasa ada jaminan karier yang jelas dalam melakukan pekerjaan.

e. Status dan tanggung jawab

Status atau kedudukan dalam jabatan tertentu merupakan dambaan bagi setiap karyawan.

f. Peraturan yang fleksibel.

\section{Nilai Motivasi Dalam Manajemen}

Adalah menjadikan tanggung jawab manajer agar proses manajemen berhasil dengan baik.Kebeberhasilan ini tergantung pada usaha manajer membangkitkan motivasi bawahannya.

Pada garis besarnya motivasi mengandung nilai-nilai,sebagai berikut :

$>$ Motivasi menentukan tingkat keberhasilan atau kegagalan perbuatan atau pekerjaan.

> Manajemen yang bermotivasi pada hakikatnya adalah manajemen yang disesuaikan dengan kebutuhan dorongan,motif,dan minat yang ada pada staf/bawahan/pelaksana.

$>$ Berhasil atau gagalnya upaya untuk membangkitkan dan menggunakan motivasi dalam manajemen erat kaitannya dengan pengaturan disiplin kerja.

$>$ Manajemen yang bermotivasi menuntut kreatifitas dan imaginitas manajer untuk berusaha secara sungguh-sungguh mencari cara-cara yang relevan dan 
serasi untuk membangkitkan dan memelihara motivasi bawahan.Manajer seharusnya berupaya agar bawahannya memiliki self motivation yang baik.

Motivasi menjadi salah satu bagian yang integral dari apda fungsi-fungsi manajemen.Penggunaan motivasi dalam manajemen turut melengkapi prosedur manajemen,dan menjadi faktor yang menentukan manajemen yang efektif

\section{Jenis-Jenis Motivasi}

Berdasarkan pengertian dan analisa tentang motivasi yang dibahas di atas,maka pokok motivasi dibagi menjadi dua jenis :

Motivasi instrinsik

Motivasi instrinsik adalah motivasi yang tercakup dalam situasi kerja dan memenuhi kebutuhan dan tujuan-tujuan staf.Motivasi ini juga disebut motivasi murni,yakni motivasi yang sebenarnya timbul dalam diri sendiri.Motivasi instrinsik adalah bersifat nyata dan motivasi sesungguhnya atau disebut istilah sound motivation.

\section{Motivasi ekstrinsik}

Motivasi ekstrinsik adalah motivasi yang disebabkan oleh faktor-faktor dari luar.Motivas ekstrinsik ini tetap diperlukan sebab tidak semua pekerjaan dapat menarik minat bawahan atau dengan kebutuhannya.Seringkali bawahan belum memahami untuk apa ia bekerja.Dalam keadaan ini motivasi terhadap bawahan perlu dibangkitkan oleh manajer agar mereka mau dan bekerja dengan lebih baik.

\section{B. KEPUASAN KERJA}

\section{Pentingnya Kepuasan Kerja}

Istilah kepuasan merujuk pada sikap umum seseorang individu terhadap pekerjaannya.Seseorang dengan tingkat kepuasan kerja yang tinggi menunjukkan sikap positif terhadap kerja.Handoko (1992), mengemukakan kepuasan kerja adalah 
keadaan emosional yang menyenangkan atau tidak menyenangkan bagi para karyawan terhadap pekerjaannya.Para manajer harus peduli akan tingkat kepuasan kerja dalam organisasi mereka dengan sekurang-kurangnya tiga alasan :

$>$ Ada bukti yang jelas bahwa karyawan yang tidak puas lebih sering melewatkan kerja dan lebih besar kemungkinan mengundurkan diri.

Telah diperagakan bahwa karyawan yang puas mempunyai kesehatan yang lebih baik dan usia yang panjang.

Kepuasan pada pekerjaan.

2. Faktor-faktor yang mempengaruhi kepuasan kerja.

Banyak faktor yang mempengaruhi kepuasan kerja karyawan.Faktor-faktor itu sendiri dalam peranannya memberikan kepuasan pada karyawan bergantung pada pribadi karyawan masing-masing.Faktor yang mempengaruh menurut Blum (dalam as'ad,2001) adalah :

$>$ Faktor individual,meliputi umur,kesehatan,watak,dan harapan.

> Faktor sosial,meliputi hubungan kekeluargaan,pandangan pekerja,kebebasan berpolitik,dan hubungan kemasyarakatan.

$>$ Faktor utama dalam pekerjaan,meliputi upah,pengawasan,kondisi kerja,kesempatan untuk maju.

\section{Survai Kepuaasan Kerja}

Survai kepuasan kerja adalah suatu prosedur tempat pegawai mengemukakan perasaan mengenai jabatan atau pekerjaannya melalui laporan kerja.Survai kepuasan kerja juga digunakan untuk mengetahui moral pegawai,pendapat,sikap,iklim,dan kualitas kehidupan kerja pegawai.

Survai kepuasan kerja dapat bermanfaat dan menguntungkan apabila memenuhi persyaratan sebagai berikut :

Manajer dan pemimpin dilibatkan diri pada survai 
Survai dirancang berdasarkan kebutuhan pegawai dan manajemen secara objektif.

Survai diadministratif secara wajar.

$>$ Ada tindak lanjut dan follow up dari pimpinan,dan adanya aksi untuk mengkomunikasikan kegunaan hasilnya dari pimpinan.

Keuntungan survai kepuasan kerja antara lain kepuasan kerja secara umum,komunikasi,meningkatkan sikap kerja,dan untuk keperluan pelatihan (training).

1. Kepuasan kerja secara umum

Keuntungan survai kepuasan kerja dpat memberikan gambaran kepada pimpinan mengenai tingkat kepuasan kerja pegawai.

2. Komunikasi

Survai kepuasan kerja sangat bermanfaat dalam mengkomunikasikan keinginan pegawai dengan pikiran pimpinan.

3. Meningkatkan sikap kerja

Survai kepuasan kerja dapat bermanfaat dalam meningkatkan sikap kerja.

4. Untuk kebutuhan pelatihan

Survai kepuasan kerja sangat berguna dalam menentukan kebutuhan pelatihan tertentu.

\section{Tipe-Tipe Survai Kepuasan Kerja.}

Ada dua tipe kepuasan kerja,yaitu tipe survai objektif dan tipe survai deskriptif.

1. Tipe survai objektif

Tipe survai objektitf yang paling popular menggunakan pertanyaanpertanyaan pilihan berganda (multiple choice).Responden membaca semua pertanyaan yang tersedia,kemudian memilih salah satu beberapa alternative jawaban yang sesuai dengan keadaannya.

2. Tipe survai deskriptif. 
Tipe survai deskriptif merupakan lawan dari tipe survai objektif.Dalam tipe survai dekkriptif.responden memberikan jawaban dari pertanyaan secara bebas sesuai dengan yang mereka inginkan.

\section{B. KAJIAN ANALITIS}

\section{Semangat Kerja}

Pegawai dapat melaksanakan pekerjaan dengan optimal apabila mereka memiliki semngat kerja.Pegawai yang memiliki semngat kerja tinggi cederung bertanggungjawab atas pekerjaannya,disamping itu pegawai yang bersemangat akan terlihat dalam kesungguhannya dalam bekerja,berpartisipasi dalam kegiatan kantor dan mempunyai kreatifitas serta sanggup bekerja sama dengan pegawai lainnya. (Ermita 2012).

Nitisemito (1999 :12) bahwa semangat kerja adalah pekerjaan yang dilakukan secara baik.lebih giat sehingga pekerjaan diharapkan dapat diselesaikan dengan lebih cepat dengan produktifitas akan meningkat.Dipertegas lagi oleh hasibuan (2005 : 94) bahwa semangat kerja adalah kemauan untuk melakukan pekerjaan dengan giat dan antusias,sehingga pekerjaan lebih cepat dan baik.Selanjutnya poewonto (2009: 83) menyatakan bahwa semangat kerja adalah reaksi emosional dan mental dari seseorang terhadap pekerjaannya.Kemudian sastrohadiwiryo (2002:282), meyatakan bahwa semangat kerja adalah suatu kondisi rohaniah perilaku individu tenaga kerja dan kelompok yang menimbulkan kesenangan yang mendalam pada diri tenaga kerja untuk bekerja dengan giat dan konsekuen dalam mencapai tujuan yang telah ditetapkan organisasi.

Berdasarkan pendapat ahli diatas dapat dikatakan bahwa semngat kerja itu sangat penting dalam mendukung pelaksanaan tugas seseorang dalam bekerja.Semangat kerja menghasilkan suatu kegiatan yang dikerjakan dengan penuh kesadaran,tanpa paksaan,sehingga pekerjaan tersebut akan dapat dikerjakan dengan cepat dan tepat.

Oleh karena itu,semangat kerja pegawai yang tinggi merupakan dorongan terciptanya suatu usaha secara maksimal dalam setiap aktivitasnya dalam mencapai tujuan 
organisasi yang telah ditetapkan.Dengan adanya semangat kerja yang tinggi ini akan memudahkan pimpinan dalam melakukan pengawasan terhadap pegawainya dalam melakukan tugas sehari-hari yang menjadi tanggung jawabnya.Sebaliknya tanpa adanya semangat kerja,maka setiap aktivitas organisasi akan mengalami gangguan,keterlambatan-keterlambatan dan bahkan hambatan yang dapat berisiko tinggi terhadap organisasi.(Ermita 2012)

\section{Pengertian Motivasi}

Motivasi adalah pemberian daya penggerak yang menciptakan kegairahan kerja seseorang,agar mereka mau bekerja sama,bekerja efektitf,terintegrasi dengan segala upaya untuk mencapai kepuasan (hasibuan,1999).

Motivasi adalah pemberian daya penggerak yang menciptakan kegairahan kerja seseorang,agar mereka mau bekerja sama,bekerja efektitf,terintegrasi dengan segala upaya untuk mencapai kepuasan.Dorongan dalam diri untuk melakukan sesuatu berpengaruh pada baik tidaknya kinerja seseorang yang menjadi, tanggungjawabnya karena guru selalu bekerja dengan penhu semangat dan gairah dalam menyelesaikan pekerjaannya.Motivasi yang tinggi dalam diri seseorang ditandai dengan munculnya keinginan untuk memperoleh hasil kerja yang memuaskan dalam melaksanakan pekerjaan,karena dengan motivasi kerja guru akan berupaya memperoleh prestasi kerja,memiliki tanggungjawab dalam melaksanakan tugas dan mencari inovasi baru (Ermita 2019)

Robbins (dalam hasibuan,1999),mengemukakan motivasi adalah suatu kerelaan berusaha seoptimal mungkin dalam pencapaian tujuan organisasi yang dipengaruhi oleh kemampuan usaha memuaskan beberapa kebutuhan individu,hamalik (1993),mengatakan ada dua prinsip yang dapat digunakan untuk meninjau motivasi,yaitu :

1. Motivasi dipadangan sebagai suatu proses.

2. Menentukan karakter dari proses ini 
Robbins (dalam hasibuan,1999), mengemukakan motivasi adalah suatu kerelaan berusaha seoptimal mungkin dalam pencapaian tujuan organisasi yang dipengaruhi oleh kemampuan usaha memuaskan beberapa kebutuhan individu.

Berdasarkan pendapat ahli diatas dapat disimpulkan bahwa motivasi adalah daya penggerak yang menciptakan kegairahan seseorang dengan suka rela berusaha semaksimal mungkin untuk mencapai tujuan organisasi.

Tanpa adanya motivasi dari para karyawan untuk bekerja,maka tujuan yang telah ditetapkan tidak akan tercapai.Sebaliknya,apabila motivasi yang tinggi dari karyawan,maka hal itu merupakan suatu jaminan atas keberhasilan suatu organisasi untuk mencapai tujuannya (gitosudarmo,2001).Oleh karena itu manejer harus menimbilkan motivas kerja yang tinggi pada karyawannya guna melaksanakan tugastugasnya,sekalipun motivasi bukan salah satu-satunya faktor yang mempengaruhi tingkat prestasi kerja seseorang.Timbulnya motivasi dikarenakan seseorang merasakan suatu kebutuhan tertentu dan karenanya perbuatan tersebut terarah pada pencapaian tujuan tertentu.

\section{Teori-Teori Motivasi}

Setiap teori motivasi berusaha untuk menguraikan apa sebenarnya manusia dan manusia dapat menjadi seperti apa.Dengan alasan apa sebenarnya motivasi mempunyai isi dalam bentuk pandangan tertentu mengenai manusia.Isi teori motivasi membantu kita untuk memanhami keterlibatan dinamis sempat orgaisasi beroperasi manggamabarkan manajer dan karyawan untuk terlibat dalam setiap organisasi.

1. Teori kepuasan

Teori ini mendasar pendekatannya atas faktor-faktor kebutuhan dan kepuasan individu yang menyebabkan bertindak dan berprilaku sesuai dengan cara-cara tertentu.Teori ini memusatkan perhatian pada faktor-faktor dalam diri orang yang menguatkan,dan mengarahkan,mendukung,dan menghentikan perilakunya.

2. Kebutuhan rasa aman (safety) 
Menurut maslow,setelah kebutuhan tingkat dasar terpenuhi,maka seseorang berusaha memenuhi kebutuhannya yang lebuh tinggi,yaitu kebutuhan akan asa aman dan keselamatan.Kebutuhan ini akan dirasakan mendesak setelah kebutuhan pertama dipebuhi.Upaya yang dilakukan untuk kebutuhan rasa aman dan keamanan ini meliputi :

> Selalu memberikan informasi agar para karyawan dalam berkerja bersikap hati-hati dan waspada.

$>$ Menyediakan tempat kerja aman dari kerutuhan

$>$ Memberikan perlindungan asuransi jiwa.

$>$ Memberikan jaminan kepastian kerja

3. Kebutuhan hubungan sosial

Kebutuhan sosial yang sering disebut dengan sosial needs,atau affliation needs,merupakan kebutuhan tingkat ketiga dari maslow.Kebutuhan ini merupakan untuk hidup bersama dengan orang lain.Kebutuhan ini hanya dapat terpenuhi bersama masyarakat,karena memang orang lainlah yang dapat memenuhinya,bukan diri sendiri.

4. Kebutuhan pengakuan (esteem)

Setiap orang yang normal membutuhkan adanya penghargaan diri dan penghargaan prestise diri dari lingkungannya.

5. Kebutuhan aktualisasi diri ( self actualization)

Kebutuhan actualisasi diri merupakan tingkat kebutuhan yang paling tinggi.Untuk memenuhi kebutuhan puncak ini biasanya seseorang bertindak bukan atas dasar dorongan orang lain,tetapi karena kesadaran dan keinginan diri sendiri.Kebutuhan aktualisasi diri mempunyai ciri-ciri yaitu ;

> Tidak dapat dipenuhi dari luar,karena harus dipenuhi dengan usaha pribadi itu sendiri,

$>$ Pemenuhan kebutuhan aktualisasi diri ini biasanya seiring dengan jenjang karier seseorang,dan tidak semua orang mempunyai tingkat kebutuha seperti ini. 


\section{B. KEPUASAN KERJA}

\section{Pengertian}

Istilah kepuasan merujuk pada sikap umum seseorang individu terhadap pekerjaannya.Seseorang dengan tingkat kepuasan kerja yang tinggi menunjukkan sikap positif terhadap kerjaHandoko (1992) ,mengemukakan kepuasan kerja adalah keadaan emosional yang menyenangkan atau tidak menyenangkan bagi para karyawan terhadap pekerjaannya. As'ad (1991),mengemukakan penelitian dibidang kepuasan kerja,terdapat tiga macam arah yaitu :

1. Usaha untuk menemukan faktor-faktor yang menjadi sumber kepuasan kerja erta kondisi-kondisi yang mempengaruhinya,dengan mengetahui hal tersebut dapat menciptakan kondisi-kondisi tertentu agar karyawan lebih bahagia dan bergairah dalam bekerja.

2. Usaha untuk melibatkan bagaimana dampak dari kepuasan kerja da tingkah laku karyawan.

3. Dalam rangka usaha mendapatkan rumusan yang lebih tepat dan bersifat komprehensif mengenai kepuasan kerja.

\section{C.PENUTUP}

1. Kesimpulan.

Motivasi adalah pemberian daya penggerak yang menciptakan kegairahan kerja seseorang,agar mereka mau bekerja sama,bekerja efektitf,terintegrasi dengan segala upaya untuk mencapai kepuasan (hasibuan,1999). Nitisemito (1999 :12) bahwa semangat kerja adalah pekerjaan yang dilakukan secara baik.lebih giat sehingga pekerjaan diharapkan dapat diselesaikan dengan lebih cepat dengan produktifitas akan meningkat. Handoko (1992) ,mengemukakan kepuasan kerja adalah keadaan

emosional yang menyenangkan atau tidak menyenangkan bagi para karyawan terhadap pekerjaannya.Jadi dapat simoulkan bahwa motivasi sangat berhubungan 
dengan semangat kerja,seseorang yang mempunyai motivasi yang tinggi dalam dirinya maka juga akan menimbulkan semangat kerja yang tinggi pula,demikian pula dengan kepuasan kerja,semakin tinggi motivasi maka semangat kerja akan meningkat dan dengan meningkatnya semangat kerja makan kepuasan kerja juga akan tercapai dengan sendirinya

2.Saran

Dalam penulisan artikel ini tentunya masih banyak terdapat kekurangan,baik dalam segi kelengkapan isi maupun cara penulisan,untuk itu kami mohon kepada rekanrekan untuk memberikan kritik dan saran yang membangun untuk penyempurnaan penulisan artikel berikutnya

\section{REFERENSI}

Ermita. (2012). Hubungan Antar Manusia dan Semangat Kerja Pegawai Oleh: Ermita Universitas Negeri Padang. PEDAGOGI,Jurnal Ilmiah Ilmu Pendidikan, $X I I(2), 70-81$.

Hamalik, O. (1993). Piskologi Manajemen Penuntun Bagi Pemimpin. Bandung: Trigenda Karya.

Mangkunegara, A. (2000). Psikologi Perusahaan. Bandung: Trigenda Karya.

Ermita. (2019). "Kontrubusi Gaya Kepemimpinan Kepala Sekolah Dan Motivasi Kerja Terhadap Kinerja Guru Di Sekolah Menengah Atas Negeri (SMAN) Kecamatan Koto Tangah Kota Padang." HIJRI, Jurnal Manajemen Pendidikan dan Keislaman 8(1): 107-23. 
